\title{
The external impacts of Central Bank independence
}

\section{Os impactos externos da independência dos Bancos Centrais}

Carroll Howard Griffin, Ph.D.

Professor of Finance of College of Global Business and Professional Studies of Fontbonne University, USA*E-mail: chgriffin@hotmail.com

Recebido em 03.08.2010 * Aceito em 15.09.2010* $2^{a}$ versão aceita em 11.11.2010.

\section{ABSTRACT}

The term "central bank independence" (or abbreviated, CBI) can be broadly defined as the degree of freedom of the central bank to pursue monetary policy without interference from political considerations. The idea of central bank independence has been widely accepted over the last several decades by many countries around the world, both developed and developing. Since being first written about academically in the late 1980s, many countries have come to adopt this policy and many governments have come to recognize this as standard procedure. As such, many countries around the world granted autonomy to their central banks during the 1980s and 1990s. The majority of past studies have examined primarily the impact of central bank independence on inflation. However, the additional theoretical benefits are much more far reaching, the result of a more stable and prosperous macroeconomic environment. Additionally, there is only now sufficient data to empirically determine whether many of these claims are true. This study examines central bank independence in developing countries of Latin America and Asia as well as selected developed countries to determine what actual impact an autonomous central bank has had. It also examines such phenomena as financial crises (including the current global crisis of 2008-2009), inflation targeting, legal systems, country development and fiscal policy to determine the effects of these items on not only inflation, but the broad spectrum of macroeconomic outcomes. Although there is some empirical evidence to support the benefits of central bank independence, it is limited in scope to certain areas.

Keywords: Central Bank Independence. Financial crisis. Latin America. Asia.

JEL Classification Code: Banks. International financial markets.

\section{RESUMO}

O termo "independência do banco central" (ou IBC) pode ser amplamente definido como o grau de liberdade que o banco central possui para seguir sua política monetária sem a interferência de considerações políticas. A ideia da independência do banco central foi aceita nas últimas décadas por muitos países ao redor do mundo, tanto desenvolvidos como em desenvolvimento. Desde a primeira literatura acadêmica a respeito no final dos anos 80, muitos países começaram a adotar essa política e muitos governos a reconheceram como padrão. Assim, muitos países ao redor do mundo concederam autonomia a seus bancos centrais nos anos 80 e 90. A maior parte dos estudos existentes investigou principalmente $o$ impacto da independência do banco central na inflação. Porém, os benefícios teóricos adicionais vão muito além, resultado de um ambiente macroeconômico mais estável e próspero. Ademais, somente agora há dados suficientes para a determinação empírica da veracidade de muitas dessas alegações. Este estudo investiga a independência dos bancos centrais em países èm desenvolvimento na América Latina e na Ásia, além de determinados países desenvolvidos, para determinar o real impacto de um banco. central autônomo. Também examina fenômenos como crises financeiras (inclusive a crise global em curso no período 2008-2009), estabelecimento de metas de inflação, sistemas legais, desenvolvimento dos 
países e política fiscal para determinar os efeitos destes itens não somente na inflação, mas no espectro amplo de resultados macroeconômicos. Apesar de haver evidências empíricas para apoiar os benefícios da independência do banco central, seu escopo é limitado a determinadas áreas.

Palavras-chave: Independência do Banco Central. Crise financeira. América Latina. Ásia.

\section{INTRODUCTION}

The term "central bank independence" (or abbreviated, CBI) can be broadly defined as the degree of freedom of the central bank to pursue monetary policy without interference from political considerations (SIRIVEDHIN; HATAISEREE, 2000). In other words, independence implies that a nation's central bank can follow a trajectory outside the political realm and does not have to abide by the government's request to follow a certain monetary policy, such as printing money to pay for federal deficits (GRUBEN; WELCH, 1993). Since being first written about academically in the late 1980s, many countries have come to adopt this policy and many governments have come to recognize this as standard procedure. From the late 1980s to the mid-1990s, countries as diverse as Malaysia, New Zealand, Chile, Mexico, Argentina, Spain, France and Brazil granted their respective central banks more autonomy from the government (CUKIERMAN, 1994). However, despite this proliferation, highly independent central banks in many countries of the developing world are a relatively new phenomenon (BOYLAN, 2001).

The idea of granting a nation's central bank autonomy from the government, although a relatively simple one at first glance, is powerful in the sense that if a central bank is independent in its decision making abilities, the government in power at a given time will be unable to turn back monetary decisions that have been made or, in a similar vein, force actions to be undertaken. Thus, in theory, an independent and autonomous central bank should lead to a more stable economic environment in the respective country (MAXFIELD, 1997). It represents a prominent transformation, because it not only removes a key aspect of economic decision making from political control, but has kept many governmental powers from overturning growth-oriented central bank policies (BOYLAN, 2001).

The primary motive behind the granting of such autonomy was the belief that an independent and sovereign central bank would have more power to diminish inflation and price volatility and thusly, economic growth would be stimulated. According to Cukierman (1994), there is widespread consensus now that central banks should be independent because it helps to achieve price stability. This belief stems not only from monetary theory but also from empirical studies on the subject, both in developed and developing countries. The traditional argument for central bank autonomy is that the power to spend money (the government) should be separate from the power to print money (the central bank).

Although there has been much study done on the theoretical rationale behind it, few empirical studies, other than those examining the effects of inflation, have been conducted to assess accurately whether central bank independence actually leads to desirable macroeconomic outcomes. That is, although many countries have granted autonomy to their respective central bank with the hope of not only taming inflation and inflation volatility, but also achieving a broader spectrum of macroeconomic goals, such as low unemployment, sustained GDP growth, increased investment, less volatile interest rates and further financial market liberalization, many of these hopes have not been proven empirically, especially in the developing world. 
The focus of this study will be to examine a select group of countries in three defined regions (Asia, Latin America, and the Developed West) and identify whether the macroeconomic variables of inflation, unemployment, and economic growth have responded positively since the granting of central bank autonomy.

\section{METHODOLOGY AND DATA}

This study will first use Ordinary Least Squares multivariate regression to test for correlation and relationships among the variables in question. Regressions will be done in a time series fashion over the time period under consideration (quarterly data for almost 50 years, to equal more than 190 observations for most time series). The "goodness of fit" ratio, or $\mathrm{R}^{2}$, will be used to gauge how well each dependent variable is explained by the independent variables. The Durbin-Watson Test will also be used for autocorrelation. A comparison of the $\mathrm{R}^{2}$ and Durbin-Watson test will be used as verification that the regression is not spurious (as mentioned above, if the Durbin-Watson results are quantitatively higher than the $\mathrm{R}^{2}$, this is a sign that the regression is not spurious, or non-sensical). Only results that are at least at the $10 \%$ statistical significance level will be listed throughout the results section and all will be listed with coefficients. Macroeconomic data from Q1:1960 to Q1:2009 will be taken entirely from the International Monetary Fund (considered a highly regarded, neutral, global financial institution) in order to maintain consistency of measurements, data collection processes and to avoid biases of individual country central banks or national data collection agencies.

\subsection{Variables}

The following independent variables will be used to examine the impact of the nuances (political and economic) of central bank independence and related phenomena on the previously mentioned dependent variables. Dummy variables are used frequently to classify data into mutually exclusive categories (GUJARATI, 2003) and will be used in the following equations to represent, among other things, the effects of country development, foreign exchange rate regimes, the occurrence of financial crises, the degree of international inflation, and the presence of legal CBI.

\section{Central Bank Independence (Legal} Date). This is a dummy variable designed to distinguish between years in which no central bank independence was in place and years in which legal central bank independence was in existence. Although for most countries it takes the value of either 0 (representing no legal independence) or 1 (representing full legal independence), it also takes the value of .5 for countries (such as Brazil) that after a certain date were operating under a semiindependent/informal accord type arrangement Source: Individual country central bank websites.

2. Modified Cukierman Index. This is a composite $\mathrm{CBI}$ index measuring various facets of independence. It was originally developed by Cukierman et al and has been recently updated. It is comprised of 18 criteria of political and economic independence with a total score ranging from zero to one. Regarding political independence, it focuses on the appointment and dismissal of the central bank's governor. The specific criteria are the following:

a.) Term of office of Governor (more than one presidential period, the period does/does not coincide with presidential elections, or not specified);

b.) Channel through which the governor is appointed (via executive and legislative, only executive etc.);

c.) Appointment and term of office for the rest of the board;

d.) Dismissal of board members; 
e.) Governor allowed to hold another government office or not;

f.) Fundamental objective of the central bank (price stability, price stability that does/ does not conflict with other economic goals etc.);

g.) Channel through which monetary policy is formulated;

h.) Government directives and resolution of conflict;

i.) Central bank involvement in debt approval;

j.) Limitations and advances on central bank lending;

k.) Lending to government (not allowed, restricted, fully allowed etc.);

1.) Channel through which financing conditions to the government are decided;

m.) Beneficiaries of central bank financing;

n.) Interest rates in advances of lending (at market rates, below or above);

o.) Lender of Last Resort;

p.) Financial autonomy;

q.) Accountability of central banks (i.e., whom do they report to and how often?);

r.) Central bank transparency (i.e., who do they disclose to and how often?) (JÁCOME; VÁZQUEZ, 2005).

\section{Grilli Masciandaro Tabellini (GMT)}

Index. This is a composite index measuring political and economic independence in various areas. It was originally developed by Grilli, Masciandaro and Tabellini in the early 1990s and has been updated since by several authors. According to the original creators of this index, credibility is the primary asset of having an independent central bank (HICKS, 2004). It is based on 15 criteria, each with a binary score of zero to one. The criteria are then simply added together. The specific criteria are the following:

a.) Appointment of the governor (with or without government involvement);

b.) Length of time of appointment (greater than or less than five years);

c.) Appointment of the board of directors (with or without government involvement); d.) Length of time of board appointment (greater than or less than five years);

e.) No mandatory participation of government representatives on the board;

f.) No government approval required in formulating monetary policy;

g.) Requirements in the charter for monetary stability to be a primary objective;

h.) Legal protections for the central bank in the event of conflict with the government;

i.) No automatic procedure for the government to obtain credit directly;

j.) Direct credit is extended to the government at market interest rates;

k.) Credit is extended on a temporary basis;

1.) Credit is extended for a limited amount;

m.) The central bank does not participate in the primary market for public debt;

n.) The central bank is responsible for setting the discount rate;

o.) The central bank has no responsibility for overseeing the banking sector (or at least shares this with other institutions) (ARNONE et al., 2006).

4. CB Governor Turnover. This has traditionally been used in the CBI literature as a proxy for independence, with the idea being that if there is a high ratio of turnover (as measured on a yearly basis), this is an indicator that the central bank is actually under the firm control of the executive branch and that the central bank governor will be dismissed if he or she does not comply with the government's demands. Therefore higher turnover is usually seen as a sign of a lesser degree of independence. See Carstens and Jácome, 2005, among others. Source: central bank websites and author's own calculations.

5. Development Dummy Variable (from 0 to 1 in .1 increments). This measures the economic development of the respective sample country in terms of Gross Domestic Product, with each .1 increment representing $\$ 3,000$ of GDP in constant dollars Source: The World Economy: Historical Statistics, OECD Development Center, 2003. 
6. Foreign Exchange Rate Regime Dummy Variable. This is designed to capture the effects of a particular type of exchange rate system on a country's economy. It takes a value of 0 for pure fixed and 1 for pure floating in .1 increments. Sources: Crowe and Meade (2008), Musa et al. (2000), Baig (2002), Bubula and Otker-Robe (2003) and IMF (2003).

7. Financial Crisis Dummy Variable. This is designed to capture the effects of financial crises on a country. It takes a value of 0 for years in which no crisis was experienced and 1 otherwise. Sources: Carstens and Jácome (2005) and author's own calculations.

8. International Inflation Dummy Variable. This is designed to control for the effects of international inflation on a country, with the idea being that many countries (including developed ones) are susceptible to outside economic forces. It takes a value from 0 to 1 in .1 increments. Sources: Jácome and Vázquez (2005) and IMF Database.

9. Inflation Targeting Regime Dummy. This is devised to capture the effects of Inflation Targeting as either a primary or secondary objective for a nation's central bank. It will take the value of 1 if IT is considered a primary objective and .5 if it is considered a secondary objective, with the value of 0 given for the years prior to IT implementation. Additionally, there will be other distinctions made, such as if a central bank (or executive branch) is monitoring inflation or has a very informal inflation goal, but has not made a formal commitment to the Inflation Targeting framework. Also, for those that have formally committed to IT, a distinction will be made between a changing yearly inflation target and a fixed target (i.e. the same goal over the course of many years), with the latter taking a higher value. Sources: Stone (2003), Agbeja (2007), central bank websites.

10. Government Consumption as a Percentage of GDP. This will be used as a proxy measure of government spending or government expenditure in order to measure the effects of fiscal policy on the dependent va- riables already described. Government consumption is considered to be government purchases of goods and services for current use (excluding military spending) and is considered to be a major portion of the gross domestic product Source: The Heritage Foundation.

11. Total Tax Revenue as a Percentage of GDP. This will also be a proxy measure of fiscal policy, representing the respective government's policy toward and ability to collect taxes relative to the size of the economy (although not a problem in developed economies, in many developing economies the government is hampered in its ability to collect tax revenues though lack of enforcement and proper tax codes). Source: Revenue Statistics, 1965-2007 (2008).

\section{Budget Surplus/Deficit as a Percen-} tage of GDP (limited availability). This will be a comprehensive proxy for fiscal stance and policy. It is often thought that a large budget deficit can be an exogenous source of inflation. To maintain a similar basis for comparison for the long time period in question, again the variable "as a \% of GDP" will be utilized. Source: Budget of the U.S. Government. Fiscal Year 2010. Office of Management and Budget (2009), International Monetary Fund IFS.

13. Forward Interest Rates (United States only). This is a proxy for market expectations of future interest rates and general economic conditions. It is representative of financial market participants' expectations. Knowledge of expectations helps a central bank to predict whether a particular policy decision is likely to surprise market participants and what their short-term response could perhaps be. Source: Federal Reserve Bank of New York.

14. Central Bank Independence (Operational Date- United States only) - the U.S. Federal Reserve has been an autonomous entity for many years (prior to the beginning of this study). However, in 2000 reforms were passed that may have increased the operational independence of the Federal Reserve. 


\subsection{Regression}

Regression analysis is one of the most useful econometric techniques in practice. According to Gujarati (2003), "Regression analysis is concerned with the study of the dependence of one variable, the dependent variable, on one or more other variables, the explanatory variables, with a view to estimating and/or predicting the mean or average value of the former in terms of the known or fixed (in repeated sampling) values of the latter" (p. 18). The basic individual regression in this study will take the following form:

$\mathrm{y}=\alpha+\beta_{1} \mathrm{CBI} 1+\beta_{2} \mathrm{CBI}_{2}+\beta_{3} \mathrm{CBI}_{3}+\ldots+\varepsilon$

The specific regressions given the independent variables described above will be the following:

Inflation Rate $=\alpha-\beta_{1}$ Development Dummy - $\beta_{2}$ Modified Cukierman Index $\beta_{3}$ GMT Index - $\beta_{4}$ Foreign Exchange Rate Re- gime Dummy $+\beta_{5}$ Financial Crisis Dummy + $\beta_{6}$ International Inflation Dummy $-\beta_{7}$ Legal Central Bank Independence Dummy + $\beta_{8}$ Central Bank Governor Turnover - $\beta_{9}$ IT Dummy $+\beta_{10}$ Cons $-\beta_{11}$ TaxRev $+\varepsilon$

GDP Volume Index $=\alpha+\beta_{1}$ Development Dummy $+\beta_{2}$ Modified Cukierman Index $+\beta_{3}$ GMT Index $+\beta_{4}$ Foreign Exchange Rate Regime Dummy $-\beta_{5}$ Financial Crisis Dummy $-\beta_{6}$ International Inflation Dummy $+\beta_{7}$ Legal Central Bank Independence Dummy $\beta_{8}$ Central Bank Governor Turnover $+\beta_{9}$ IT Dummy $-\beta_{10}$ Cons $+\beta_{11}$ TaxRev $+\varepsilon$

Unemployment $\%=\alpha-\beta_{1}$ Development Dummy $-\beta_{2}$ Modified Cukierman Index - $\beta_{3}$ GMT Index - $\beta_{4}$ Foreign Exchange Rate Regime Dummy $+\beta_{5}$ Financial Crisis Dummy + $\beta_{6}$ International Inflation Dummy $-\beta_{7}$ Legal Central Bank Independence Dummy + $\beta_{8}$ Central Bank Governor Turnover $-\beta_{9}$ IT Dummy $+\beta_{10}$ Cons $-\beta_{11}$ TaxRev $+\varepsilon$

\section{RESULTS AND INTERPRETATION}

\subsection{External impacts}

For the next set of hypotheses, a representative country for each level will be examined for Inflation, GDP Volume and Unemployment to ascertain to what degree (if any) these variables are influenced by the fiscal policy variable in question.

\subsubsection{Fiscal Policy}

H1- There is stronger evidence of CBI effectiveness among countries that have a higher level of Tax Revenue amassed by the government (Table 1a $\mathbf{0}$ ).
There is some evidence regarding Inflation and CBI effectiveness when examined through Tax Revenue levels (as seen in the case of New Zealand). This also lends support to fiscal policy theory (i.e. a decrease/ increase in taxes is part of expansionary/ contractionary fiscal policy, leading to more/ less output and, in many cases, higher/lower inflation levels) that there is an inverse relationship between Tax Revenue and Inflation at the highest Tax Revenue level.

b) GDP Growth (Table 1b $\theta$ ).

Table 1a Inflation results: tax revenue

\begin{tabular}{l|l|l|c}
\multicolumn{1}{c|}{ Level } & $\mathbf{R}^{2}$ & DW & Significant Variables (Coefficients) \\
\hline High (New Zealand) & .32 & 1.16 & FXD (.99), GMT (-.16) \\
\hline Medium High (Malaysia) & .23 & 1.51 & II (.91), IT (4.52), FXD (.87) \\
\hline Medium (Mexico) & .66 & 1.16 & CBGov (-.01), DD (-3.63), II (.06) \\
\hline Medium Low (Philippines) & .45 & 1.55 & CBGov (-.76), FCD (1.51), II (.92) \\
\hline Low (India) & .40 & 1.92 & FCD (1.68), II (.73), IT (2.43) \\
\hline
\end{tabular}


Table 1b GDP volume index results: tax revenue

\begin{tabular}{l|c|c|c}
\multicolumn{1}{c|}{ Level } & $\mathbf{R}^{\mathbf{2}}$ & DW & Significant Variables (Coefficients) \\
\hline High (New Zealand) & .07 & 2.45 & FCD (-1.19) \\
\hline Medium High (Malaysia) & .19 & 2.10 & FCD (-1.98), IT (-12.10) \\
\hline Medium (Mexico) & .12 & 3.40 & DD (22.60), FCD (-2.88), Surplus (-1.16) \\
\hline Medium Low (Philippines) & .01 & 3.24 & None \\
\hline Low (India) & .03 & 1.87 & None \\
\hline
\end{tabular}

There is no evidence of greater/less CBI effectiveness as it pertains to level of Tax Revenue amassed by the government. However, it is of note that the Financial Crisis Dummy variable is consistently statistically negatively related to GDP growth throughout.

\section{c) Unemployment (Table 1c $\mathbf{O})$.}

Legal CBI effectiveness as it relates to Unemployment can be observed at the Medium High Level of Tax Revenue. The Financial Crisis Dummy also appears.

H2- There is stronger evidence of CBI effectiveness among countries that have a higher level of Government Consumption (Table 2a $\mathbf{O}$ ).
There is no evidence of greater legal or operational CBI effectiveness at higher levels of Government Consumption. However, it is noteworthy that at higher levels of Government Consumption, the coefficients support fiscal policy theory. In other words, an increase in government consumption (i.e. demand) tends to lead to an increase in inflation. However, at lower levels of consumption, perhaps this does not hold true. In other words, there may exist a type of "breaking point" related to inflation as consumption increases. It is also noteworthy that there is a strong statistical correlation between international inflation levels (as denoted by the variable

Table 1c Unemployment results: tax revenue

\begin{tabular}{l|c|c|c}
\multicolumn{1}{c|}{ Level } & Adj. $\mathbf{R}^{\mathbf{2}}$ & DW & Significant Variables (Coefficients) \\
\hline High (New Zealand) & .08 & 2.33 & None \\
\hline Medium High (Malaysia) & .14 & 2.47 & LCBI (-.22), FXD (.33) \\
\hline Medium (Mexico) & .14 & 2.92 & Surplus $(.12)$ \\
\hline Medium Low (Philippines) & .00 & 2.80 & None \\
\hline Low (India) & & & Not Available \\
\hline
\end{tabular}

Table 2a Inflation results: government consumption

\begin{tabular}{|c|c|c|c|}
\hline Level & Adj. $\mathbf{R}^{2}$ & DW & Significant Variables (Coefficients) \\
\hline High (England) & .26 & 1.72 & $\begin{array}{c}\text { DD (1.80), FCD (-.64), } \\
\text { Cons (.07), II (.78), LCBI (.66) }\end{array}$ \\
\hline Medium High (Brazil) & .46 & 1.06 & GMT (2.36), II (9.11) \\
\hline Medium (China) & .19 & .96 & $\mathrm{DD}(22.74), \mathrm{FXD}(4.53)$ \\
\hline Medium Low (India) & .40 & 1.92 & FCD (1.68), II (.73), IT (2.43) \\
\hline Low (Argentina) & .51 & .98 & $\begin{array}{c}\text { CBGov (.00), DD (-.01), FCD (.00), } \\
\text { GMT (-10.26), Cons (.00), II (.73), LCBI } \\
\text { (62.06), MCI (8.06), TaxRev (6.11) }\end{array}$ \\
\hline
\end{tabular}


"II") and country inflation in the case of Brazil, which was deemed to possess medium high levels of government consumption (although not causal proof, it perhaps signifies that international inflation levels may have influenced levels in this country over the years).

b) GDP Growth (Table 2b $\mathbf{\nabla}$ ).

There is no evidence of greater CBI effectiveness at higher levels of Government Consumption as it pertains to GDP Volume.

c) Unemployment (Table 2c $\boldsymbol{\nabla}$ ).

There is no evidence of greater CBI effectiveness at higher levels of Consumption as it relates to Unemployment. However, again, the Financial Crisis variable is positively correlated with Unemployment (in the case of Low Consumption).

\subsubsection{Social and political factors}

For the next set of hypotheses, a representative country for each level will be examined for Inflation, GDP Volume and Unemployment to ascertain to what degree (if any) these variables are influenced by the social and political factors in question.

H3- There is stronger evidence of CBI effectiveness among countries with lower levels of Corruption.

a) Inflation (Table $3 a \boldsymbol{\nabla}$ ).

As can be seen, the effect of legal and/ or operational independence is moderately strong at low levels of corruption but loses strength as corruption levels increase. For example, in the case of Brazil, which is classified as having medium levels

Table 2b GDP volume index results: government consumption

\begin{tabular}{l|c|c|c}
\multicolumn{1}{c|}{ Level } & Adj. $\mathbf{R}^{2}$ & DW & Significant Variables (Coefficients) \\
\hline High (England) & .11 & 2.20 & II (-.64), TaxRev (.14) \\
\hline Medium High (Brazil) & & & Unavailable \\
\hline Medium (China) & & & Unavailable \\
\hline Medium Low (India) & .03 & 1.87 & None \\
\hline Low (Argentina) & .04 & 3.15 & None \\
\hline
\end{tabular}

Table 2c Unemployment results: government consumption

\begin{tabular}{l|c|c|c}
\multicolumn{1}{c|}{ Level } & Adj. $\mathbf{R}^{\mathbf{2}}$ & DW & Significant Variables (Coefficients) \\
\hline High (England) & .09 & 1.82 & None \\
\hline Medium High (Brazil) & .10 & 2.06 & None \\
\hline Medium (China) & .10 & 2.13 & FXD (-.20) \\
\hline Medium Low (India) & & & Not Available \\
\hline Low (Argentina) & .17 & 2.26 & FCD (.75), II (1.64), TaxRev (-.70) \\
\hline
\end{tabular}

Table 3a Inflation results: corruption levels

\begin{tabular}{l|c|c|c}
\multicolumn{1}{c|}{ Level } & $\mathbf{R}^{\mathbf{2}}$ & DW & Significant Variables (Coefficients) \\
\hline Low (New Zealand) & .32 & 1.16 & FXD (.99), GMT (-.16) \\
\hline Medium (Brazil) & .46 & 1.06 & GMT (2.36), II (9.11) \\
\hline High (Argentina) & .51 & .98 & $\begin{array}{r}\text { CBGov (.00), DD (-.01), FCD (.00), } \\
\text { GMT (-10.26), Cons (.00), II (.73), } \\
\text { LCBI (62.06), MCI (8.06), TaxRev (6.11) }\end{array}$ \\
\hline
\end{tabular}


of corruption, the GMT index is actually positively correlated with inflation in this analysis.

\section{b) GDP Growth (Table 3b 0).}

There is no evidence of greater CBI effectiveness on GDP growth when examined by levels of country corruption.

\section{c) Unemployment (Table 3c $\boldsymbol{\nabla}$ ).}

There is no evidence of greater CBI effectiveness in low corruption countries as it pertains to Unemployment. However, there is evidence of correlation between financial crises and Unemployment in high corruption countries.
H4- There is stronger evidence of CBI effectiveness among countries operating under English Common Law than other types of legal systems.

a) Inflation (Table $4 \mathrm{a} \boldsymbol{\nabla})$.

Regarding Inflation, there is conflicting evidence. In other words, there is evidence of operational and legal CBI with coefficients of different directions (in French Civil and Germanic Law countries).

b) GDP Growth (Table 4b $\mathbf{\nabla})$.

In the area of economic growth, there is no evidence of greater CBI effectiveness as it pertains to legal systems.

Table 3b GDP volume index results: corruption levels

\begin{tabular}{l|c|c|c}
\multicolumn{1}{c|}{ Level } & Adj. $\mathbf{R}^{\mathbf{2}}$ & DW & Significant Variables (Coefficients) \\
\hline Low (New Zealand) & .07 & 2.45 & FCD (-1.19) \\
\hline Medium (Brazil) & & & Not Available \\
\hline High (Argentina) & .04 & 3.15 & None \\
\hline
\end{tabular}

Table 3c Unemployment results: corruption levels

\begin{tabular}{l|c|c|c}
\multicolumn{1}{c|}{ Level } & Adj. $\mathbf{R}^{\mathbf{2}}$ & DW & Significant Variables (Coefficients) \\
\hline Low (New Zealand) & .08 & 2.33 & None \\
\hline Medium (Brazil) & .10 & 2.06 & None \\
\hline High (Argentina) & .17 & 2.26 & FCD (.75), II (1.64), TaxRev (-.70) \\
\hline
\end{tabular}

Table 4a Inflation results: legal system

\begin{tabular}{l|c|c|c}
\multicolumn{1}{c|}{ Legal System } & Adj. $\mathbf{R}^{\mathbf{2}}$ & DW & Significant Variables (Coefficients) \\
\hline English Common (U.S.) & .38 & 2.17 & Cons (.49), Deficit (.52), Forward (.20) \\
\hline French Civil (Mexico) & .74 & 1.50 & $\begin{array}{c}\text { DD (-5.36), FCD (.61), FXD (3.34), GMT } \\
(.96), \text { II (.64), LCBI (-5.93), TaxRev (-.29) }\end{array}$ \\
\hline Germanic (Japan) & .36 & 2.17 & $\begin{array}{r}\text { DD(-1.58), FCD (.42), II (1.51), LCBI } \\
(-1.05), \mathrm{MCl}(6.70), \text { TaxRev (-.06) }\end{array}$ \\
\hline
\end{tabular}

Table 4b GDP volume index results: legal system

\begin{tabular}{l|c|c|c}
\multicolumn{1}{c|}{ Legal System } & Adj. $\mathbf{R}^{\mathbf{2}}$ & DW & Significant Variables (Coefficients) \\
\hline English Common (U.S.) & .51 & 2.22 & $\begin{array}{r}\text { Cons (.35), II (-1.07), Surplus (.19), } \\
\text { OCBI (-8.57), Forward (.26) }\end{array}$ \\
\hline French Civil (Mexico) & .12 & 3.40 & DD (22.60), FCD (-2.88), Surplus (-1.16) \\
\hline Germanic (Japan) & .01 & 2.60 & None \\
\hline
\end{tabular}


c) Unemployment (Table 4c $\boldsymbol{\nabla}$ ).

There seems to be a mixed pattern regarding Unemployment and CBI here as well.

H5- There is stronger evidence of CBI effectiveness among countries operating under Inflation Targeting regimes.

a) Inflation (Table $5 \mathrm{a} \boldsymbol{\nabla})$.

Although intuitively, one might think that countries operating under high inflation targeting regimes would also see greater CBI effectiveness related to Inflation, there is no evidence to support this. However, there is actually a negative relationship between FCD and Inflation in En- gland (High IT); leading one to think that perhaps an IT regime is useful under certain circumstances.

\section{b) GDP Growth (Table 5b $\boldsymbol{\nabla})$.}

c) Unemployment (Table 5c $\boldsymbol{\nabla}$ ).

There is no evidence to support the hypothesis of greater CBI effectiveness under high IT regimes as it relates to either GDP growth or Unemployment.

H6- There is stronger evidence of CBI effectiveness among countries operating under a medium level of constraints than either a high or low level of constraints.

Table 4c Unemployment results: legal system

\begin{tabular}{l|c|c|c}
\multicolumn{1}{c|}{ Legal System } & Adj. $\mathbf{R}^{\mathbf{2}}$ & DW & Significant Variables (Coefficients) \\
\hline English Common (U.S.) & .44 & 2.80 & Cons (-.40), Surplus (-.42) \\
\hline French Civil (Mexico) & .14 & 2.92 & Surplus (.12) \\
\hline Germanic (Japan) & .13 & 2.27 & DD (-.95), GMT (.13), \\
\hline
\end{tabular}

Table 5a Inflation results: inflation targeting

\begin{tabular}{l|c|c|c}
\multicolumn{1}{c|}{ Level } & Adj. $\mathbf{R}^{2}$ & DW & Significant Variables (Coefficients) \\
\hline High (England) & .26 & 1.72 & $\begin{array}{c}\text { DD (1.80), FCD (-.64), } \\
\text { Cons (.07), II (.78), LCBI (.66) }\end{array}$ \\
\hline Medium (U.S.) & .38 & 2.17 & Cons (.49), Deficit (.52), Forward (.20) \\
\hline Low (India) & .40 & 1.92 & FCD (1.68), II (.73), IT (2.43) \\
\hline
\end{tabular}

Table 5b GDP volume index results: inflation targeting

\begin{tabular}{l|c|c|c}
\multicolumn{1}{c|}{ Level } & Adj. $\mathbf{R}^{2}$ & DW & Significant Variables (Coefficients) \\
\hline High (England) & .11 & 2.20 & II (-.64), TaxRev (.14) \\
\hline Medium (U.S.) & .51 & 2.22 & $\begin{array}{r}\text { Cons (.35), II (-1.07), Surplus (.19), } \\
\text { OCBI (-8.57), Forward (.26) }\end{array}$ \\
\hline Low (India) & .03 & 1.87 & None \\
\hline
\end{tabular}

Table 5c Unemployment results: inflation targeting

\begin{tabular}{l|c|c|c}
\multicolumn{1}{c|}{ Level } & Adj. $\mathbf{R}^{\mathbf{2}}$ & DW & Significant Variables (Coefficients) \\
\hline High (England) & .09 & 1.82 & None \\
\hline Medium (U.S.) & .44 & 2.80 & Cons (-.40), Surplus (-.42) \\
\hline Low (India) & & & Not Available \\
\hline
\end{tabular}


a) Inflation (Table $6 a \boldsymbol{\nabla}$ ).

There is some evidence that there is greater CBI effectiveness under high constraint levels as it relates to Inflation.

\section{b) GDP Growth (Table 6b $\mathbf{0})$.}

c) Unemployment (Table 6c $\boldsymbol{\nabla}$ ).

There is no evidence that there is any greater CBI effectiveness for GDP growth or Unemployment as they pertain to constraint levels.
H7- There is stronger evidence of CBI effectiveness among countries that are more economically developed (Table 7a $\mathbf{0}$ ).

As can be seen above, there is moderate evidence that countries that are more economically developed have greater CBI effectiveness in regards to Inflation.

b) GDP Growth (Table 7b $\oslash$ ).

c) Unemployment (Table 7c $\theta$ ).

Table Ga Inflation results: constraint level

\begin{tabular}{l|c|c|c}
\multicolumn{1}{c|}{ Level } & $\mathbf{R}^{2}$ & DW & Significant Variables (Coefficients) \\
\hline High (New Zealand) & .32 & 1.16 & FXD (.99), GMT (-.16) \\
\hline Medium High (U.S.) & .38 & 2.17 & Cons (.49), Deficit (.52), Forward (.20) \\
\hline Medium (Mexico) & .66 & 1.16 & CBGov (-.01), DD (-3.63), II (.06) \\
\hline Medium Low (China) & .19 & .96 & DD (22.74), FXD (4.53) \\
\hline Low (Indonesia) & .43 & 1.29 & FCD (2.49), IT (6.55), FXD (2.07) \\
\hline
\end{tabular}

Table $\mathbf{6 b}$ GDP volume index results: constraint level

\begin{tabular}{l|c|c|c}
\multicolumn{1}{c|}{ Level } & $\mathbf{R}^{\mathbf{2}}$ & DW & Significant Variables (Coefficients) \\
\hline High (New Zealand) & .07 & 2.45 & FCD (-1.19) \\
\hline Medium High (U.S.) & .51 & 2.22 & Cons (.35), II (-1.07), Surplus (.19), OCBI (-8.57), Forward (.26) \\
\hline Medium (Mexico) & .12 & 3.40 & DD (22.60), FCD (-2.88), Surplus (-1.16) \\
\hline Medium Low (China) & & & Unavailable \\
\hline Low (Indonesia) & .14 & 2.46 & None \\
\hline
\end{tabular}

Table 6c Unemployment results: constraint level

\begin{tabular}{l|l|l|c}
\multicolumn{1}{c|}{ Level } & $\mathbf{R}^{\mathbf{2}}$ & DW & Significant Variables (Coefficients) \\
\hline High (New Zealand) & .08 & 2.33 & None \\
\hline Medium High (U.S.) & .44 & 2.80 & Cons (-.40), Surplus (-.42) \\
\hline Medium (Mexico) & .14 & 2.92 & Surplus (.12) \\
\hline Medium Low (China) & .10 & 2.13 & FXD (-.20) \\
\hline Low (Indonesia) & & & Unavailable \\
\hline
\end{tabular}

Table 7a Inflation results: economic development

\begin{tabular}{l|c|c|c}
\multicolumn{1}{c|}{ Level } & $\mathbf{R}^{\mathbf{2}}$ & DW & Significant Variables (Coefficients) \\
\hline High (Japan) & .36 & 2.17 & DD(-1.58), FCD (.42), II (1.51), LCBI (-1.05), MCI (6.70), TaxRev (-.06) \\
\hline Medium High (Spain) & .18 & 2.51 & CBGov (-1.40), FCD (-.68), Cons (.11), TaxRev (-.04) \\
\hline Medium (Chile) & .49 & 1.30 & MCI (-1.41), II (1.26), DD (6.83) \\
\hline Medium Low (Peru) & .13 & 1.66 & None \\
\hline Low (Philippines) & .45 & 1.55 & FCD (1.51), CBGov (-.76), II (.92) \\
\hline
\end{tabular}


Regarding GDP growth and Unemployment, is any relationship between a country's econothere is little (or conflicting) evidence that there mic development and the effectiveness of CBI.

Table 7b GDP volume index results: economic development

\begin{tabular}{l|l|l|c}
\multicolumn{1}{c|}{ Level } & $\mathbf{R}^{2}$ & DW & Significant Variables (Coefficients) \\
\hline High (Japan) & .01 & 2.60 & None \\
\hline Medium High (Spain) & .36 & 2.17 & CBGov (-1.82), LCBI (-.78), \\
\hline Medium (Chile) & .07 & 2.81 & IT (1.36), FCD (-1.16), TaxRev (.04) \\
\hline Medium Low (Peru) & .03 & 1.75 & None \\
\hline Low (Philippines) & .01 & 3.24 & None \\
\hline
\end{tabular}

Table 7c Unemployment results: economic development

\begin{tabular}{l|c|c|c}
\multicolumn{1}{c|}{ Level } & $\mathbf{R}^{\mathbf{2}}$ & DW & Significant Variables (Coefficients) \\
\hline High (Japan) & .13 & 2.27 & $\begin{array}{r}\text { DD (-.95), GMT (.13), } \\
\text { LCBI (.40), MCI (-1.77) }\end{array}$ \\
\hline Medium High (Spain) & .27 & 2.26 & FCD (1.20), DD (2.72), TaxRev (-.05) \\
\hline Medium (Chile) & .07 & 2.07 & FXD (-2.66) \\
\hline Medium Low (Peru) & .02 & 1.66 & None \\
\hline Low (Philippines) & .00 & 2.80 & None \\
\hline
\end{tabular}

\section{CONCLUSION}

The following figure is a summary of the findings from the above hypotheses (Figure $1 \mathbf{0}$ ).

The idea of central bank independence has been at the forefront of financial market liberalization since the late 1980s and is still quite relevant (HAAN et al., 2008). Many countries around the world, both developed and developing, have granted autonomy to their central banks in order to achieve monetary and fiscal objectives. There are several

1. Regarding Inflation and Unemployment, there seems to be some evidence that level of tax revenue is correlated with $\mathrm{CBI}$ effectiveness. However, there is no evidence regarding GDP growth.

2. There is no evidence of greater $\mathrm{CBI}$ effectiveness in any of the three variables when examined under the lens of Government Consumption.

3. For Inflation, a low level of corruption is linked to CBI effectiveness (as expressed by operational and/or legal independence). For GDP growth and Unemployment, there is no apparent link.

4. There is little to no evidence of any difference in $\mathrm{CBI}$ effectiveness when examined on the basis of a country's legal system.

5. There seems to be no clear link between CBI effectiveness and the level of Inflation Targeting as they relate to any of the key variables.

6. Regarding Inflation, there is some evidence of greater $\mathrm{CBI}$ effectiveness under high constraint levels. For GDP growth and Unemployment, there is no evidence of a relationship.

7. There is moderate support for greater $\mathrm{CBI}$ effectiveness in more economically developed countries as it relates to Inflation. However, there is little to no evidence of such regarding GDP growth or Unemployment.

Figure 1 Summary of findings 
general motives put forth in the literature as to what macroeconomic and political events drove countries to grant this authority. However, the results in the early literature on the subject, with some exceptions, seemed to come to a common conclusion that an in- crease in central bank independence would lead to a lowering in inflation rates. However, much of the early work was done in the early to mid-1990s, before many of the developing and developed world's central banks had achieved independence.

\section{Referências}

AGBEJA, O. Central bank independence and inflation targeting: monetary policy framework for Sub-Saharan Africa. The International Journal of Applied Economics and Finance, v. 1, n. 1, p. 29-37, 2008.

ARNONE; M.; LAURENS, B.; SEGALOTTO, J. Measures of central bank autonomy: empirical evidence for OECDs, developing, and emerging market economies. IMF Working Paper, v. 6, p. 228, 2006.

BAIG, T. Characterizing exchange rate regimes in postcrisis East Asia. IMF Working Paper, v. 01, p. 152, 2002. BOYLAN, D. Defusing democracy: central bank autonomy and the transition from authoritarian rule, 2001. BUBULA, A.; OTKER-ROBE, I. The evolution of exchange rate regimes since 1990: evidence from de facto policies. IMF Working Paper, v. 2, p. 155, 2003.

BUDGET of the U.S. Government. Fiscal Year 2010. Office of Management and Budget, p. 127-128, 2010. CARSTENS, A.; JÁCOME, L. Latin American central bank reform: progress and challenges. IMF Working Paper, v. 5, p. 114, 2005.

CROWE, C.; MEADE, E. Central bank independence and transparency: evolution and effectiveness. IMF Working Paper, v. 8, p. 119, 2008.

CUKIERMAN, A. Central bank independence and monetary control. The Economic Journal, v. 104, p. 1437 $1448,1994$.
GRUBEN, W.; WELCH, J. Interpreting central bank independence in Mexico. Federal Reserve Bank of Dallas, 1993.

GUJARATI, D. Basic econometrics. 4. ed. McGraw-Hill Publishers, 2003.

INTERNATIONAL Monetary Fund. Disponível em: $<$ www.imf.org $>$.

JÁCOME, L.; VÁZQUEZ, F. Any link between legal central bank independence and inflation? evidence from Latin America and the Caribbean. IMF Working Paper, v. 5 , p. 75,2005 .

MAXFIELD, S. Gatekeepers of growth: the international political economy of central banking in developing countries. Princeton, NJ: Princeton University Press, 1997.

MUSSA, M. et al. Exchange rate regimes in an increasingly integrated world economy. International Monetary Fund. Occasional Paper, v. 193, p. 45, 2000. OECD. The World economy: historical statistics. Paris, France: OECD Development Center, 2003. REVENUE Statistics, 1965-2007, 2008 Edition. SIRIVEDHIN, T.; HATAISEREE, R. Central bank independence: a thai perspective. Seanza Advisors Meeting, 2000.

STONE, M. Inflation targeting lite. IMF Working Paper, v. 3, p. 12, 2003. 